\title{
Differential Expression of HTR2A and MAOA Genes in the Prefrontal Cortex and Hypothalamus of Suicide Victims from a Mexican Population
}

\section{Daniel Francisco Ramos}

Universidad Juarez del Estado de Durango Facultad de Ciencias Químicas

\section{Edna Madai Mendez}

Universidad Juarez del Estado de Durango Instituto de Investigación Científica

José Manuel Salas

Universidad Juarez del Estado de Durango Instituto de Investigación Científica

\section{Alma Cristina Salas}

Universidad Juarez del Estado de Durango Instituto de Investigación Científica

Norma Urtiz

Universidad Juarez del Estado de Durango Facultad de Ciencias Químicas

Marcelo Barraza ( $\nabla$ mbsalas@ujed.mx )

Universidad Juarez del Estado de Durango

\section{Research article}

Keywords: Suicide, HTR2A, MAOA, Gene Expression, Postmortem brain, Mexican Population.

Posted Date: July 30th, 2020

DOl: https://doi.org/10.21203/rs.3.rs-42474/v1

License: () (1) This work is licensed under a Creative Commons Attribution 4.0 International License.

Read Full License 
Differential Expression of HTR2A and MAOA Genes in the Prefrontal Cortex and Hypothalamus of Suicide Victims from a Mexican Population

5

Daniel Ramos-Rosales ${ }^{1}$, Edna Méndez-Hernández ${ }^{2}$, José Salas-Pacheco ${ }^{2}$, Alma Salas-Leal ${ }^{2}$, Norma Urtiz-Estrada $^{1}$ and Marcelo Barraza-Salas ${ }^{1^{*}}$

8

$9{ }^{1}$ Facultad de Ciencias Químicas, Universidad Juárez del Estado de Durango, Av. Veterinarias S/N, 10 Circuito Universitario, 34120 Durango, Dgo., México. CP 34120, Durango, México

$11{ }^{2}$ Instituto de Investigación Científica, Universidad Juárez del Estado de Durango, Universidad y 12 Fanny Anitua SN, Zona Centro, Durango, Dgo. México, CP 34000, Durango, México.

13

14

* Correspondence:

15

Marcelo Barraza-Salas

16

Facultad de Ciencias Químicas, Universidad Juárez del Estado de Durango, Av. Veterinarias S/N,

17 Circuito Universitario, 34120 Durango, Dgo., México. CP 34120

18 Email: mbsalas@ujed.mx

19 Telephone number: 044 618-1-58-41-51

20 
27 Background: Suicide is a major public health concern that has been associated with several 28 neurobiological abnormalities, including dysfunction of the serotonin (5-HT) neurotransmission system. The serotonin $2 \mathrm{~A}$ receptor $\left(5-\mathrm{HT}_{2 \mathrm{~A}}\right)$ and the monoamine oxidase $\mathrm{A}$ enzyme (MAO-A), which is responsible for degrading $5-\mathrm{HT}$, are encoded by the HTR2A and MAOA genes, respectively.

31 These genes have been associated with several psychiatric disorders and an increased risk for 32 suicide.

Methods: Our study examined the expression levels of HTR2A and MAOA genes in the postmortem prefrontal cortex (Brodmann area 8/9) and hypothalamus (ventromedial nucleus) tissues from 15 suicide victims and 15 control subjects from a Mexican population. Geneexpression profile quantification was carried out by qPCR and determined by the $2^{-\Delta \Delta C t}$ method. Results: In suicide victims, the expression levels of the HTR2A gene were significantly higher in the prefrontal cortex. In contrast, the expression of the MAOA gene in the hypothalamus of the suicide victims was significantly higher than in the control subjects. When comparing adult controls against adult suicidal victims (25-59 year-old age group), a significant decrease in HTR2A

41 expression in the hypothalamus was observed. These results were consistent regardless of age, 42 sex, postmortem interval, or $\mathrm{pH}$ of brain tissue.

43 Conclusions: The evidence suggests that the pattern of differential expression of the HTR2A and MAOA genes in the brain may be involved in suicide, providing a possible molecular basis for the brain abnormalities in suicide victims. 
51 Background

52 Suicide is a serious global public health concern and is the third leading cause of death in 15-19-

53 year-olds. Globally, 800,000 individuals die by suicide each year [1]. In Mexico, from 2000 to 2015,

54 the suicide rate increased from 5.95 to 8.50 in men (per 100,000 inhabitants) and from 1.06 to

552.00 in women [2]. Neurobiological abnormalities link serotonin (5-HT) dysfunction to suicidal

56 tendencies [3]. There is accumulating evidence that highlights a significant decrease in the primary

57 metabolite of 5-HT, 5-hydroxyindoleacetic acid (5-HIAA) in the cerebrospinal fluid of depressed

58 patients who had attempted suicide [4, 5], and postmortem brain tissue of suicide victims [6],

59 which supports the serotonin hypothesis of suicide [7]. Several studies have shown abnormal

60 expression of serotonin-related genes in suicide and suicidal behavior [8]. The HTR2A and MAOA

61 genes have been considered as candidates for suicide risk $[9,10]$.

62

63 The HTR2A gene is located on chromosome 13q14.2 and encodes the serotonin-2A receptor (5-

$\left.64 \mathrm{HT}_{2 \mathrm{~A}}\right)$. This receptor is widespread throughout the frontal lobes and many structures of the limbic

65 system [11]. Several studies [12-14] have suggested that there is an increase in the binding and

66 density of this receptor in the prefrontal cortex of suicide victims, as well an increase in the HTR2A

67 expression levels in the frontal cortex and hippocampus of teenage suicides [15].

68

69 The MAOA gene is located on chromosome Xp21-p11 and encodes the monoamine oxidase A

70 enzyme (MAO-A), which is involved in the degradation process for various monoamines, including

$715-\mathrm{HT}[16]$. The higher activity alleles of the MAO-A gene are associated with vulnerability to suicide

$72[17,18]$. An increase in the activity of this enzyme was observed in the hypothalamic region of

73 suicide victims [19]. 
74 MAOA gene KO mice have revealed that have increased concentrations of monoamines, including

75 5-HT, increasing the aggression levels [20]; similar findings have been reported in human males

76 [21]. Furthermore, the attenuation of the $5-\mathrm{HT}_{2 \mathrm{~A}}$ receptor leads to the onset of depression and

77 anxiety-related behaviors [22]. It has been suggested that the frequency of suicidal behavior and

78 the severity of suicidal ideation in depressed patients is often related to aggressive traits [23].

79

80 Most of the studies have been exclusively performed in the Caucasian population. There are no

81 reports of the expression patterns of HTR2A and MAOA genes in the brain of suicide victims from

82 the Latino population.

83

Methods

85 The aim of the present study was to investigate whether the expression levels of the HTR2A and MAOA genes are altered in the postmortem brain of suicide victims from a Mexican population.

87

\section{Subjects}

89 This study was approved by the Ethics Committee of the General Hospital of Durango. Postmortem brain tissue was obtained from the Forensic Medical Services of the General Fiscally of the State of

91 Durango, Mexico. Brain samples were free of neuropathological abnormalities as well as human

92 immunodeficiency virus and hepatitis $C$ virus antibodies. The written informed consent forms were

93 signed by first-degree relatives. The studies were performed in the prefrontal cortex (Brodmann

94 area 8/9) and hypothalamus (ventromedial nucleus) obtained from 15 suicide victims and 15

95 normal subjects (death by causes not associated with impulsive or reckless behaviors, such as

96 workplace accident, motor vehicle accident, myocardial infarction, drowning, etc.), here in

97 referred to as control subjects. Psychiatric diagnoses were characterized based on data obtained 
from a clinical interview with first-degree relatives, which contained information about (I) medical records (II) psychiatric records, (III) declarations from the police and witnesses, (IV) demographic information, (V) acute and chronic stressful life situations, and (VI) substance abuse records. Exclusion criteria for brain samples included the presence of significant structural brain pathology on postmortem examination and history of central nervous system disease. The postmortem interval (PMI) represents the time interval between the estimated time of death and the sample collection, which was established as less than 16 hours. The subjects included in this work had a common ethnic origin.

The prefrontal cortex was defined as the gray matter obtained from the right hemisphere. The samples were dissected during the autopsy and kept at $-80^{\circ} \mathrm{C}$ in RNAlater (Invitrogen, CA, USA).

\section{RNA extraction and determination of expression pattern}

Total RNA was isolated from $30 \mathrm{mg}$ of homogenized tissue in Trizol (Life Technologies, Carlsbad, CA, USA) using the Direct-zol RNA Miniprep kit (Zymo Research Corporation, Irvine, CA, USA) according to manufacturer protocol. The RNA concentration and purity were measured by a NanoDrop 2000 spectrophotometer (Thermo Fisher Scientific Inc., Germering, Germany). Total RNA was confirmed by $1 \%$ agarose gel electrophoresis. The first-strand cDNA was then generated from $1 \mu \mathrm{g}$ of template RNA using a SureCycler 8800 Thermal Cycler (Agilent, Santa Clara, CA, USA) and High-Capacity cDNA Reverse Transcription Kit (Applied Biosystems, Carlsbad, CA, USA) in a 20 $\mu \mathrm{L}$ reaction, according to the instructions. Priming was performed at $25^{\circ} \mathrm{C}$ for $10 \mathrm{~min}$, reverse transcription for $120 \mathrm{~min}$ at $37^{\circ} \mathrm{C}$, and the final step at $85^{\circ} \mathrm{C}$ for $5 \mathrm{~min}$ using a mixture of oligo-dT primers and random primers. The CDNA was then stored at $-20^{\circ} \mathrm{C}$ for subsequent analysis. 
122

123

124

125

126

127

128

129

130

131

132

133

134

135

136

137

138

139

140

141

142

143

144

145

Foster City, CA), using the TaqMan Gene Expression Assays; HTR2A (Hs01033524_m1), and MAOA (Hs00165140_m1). The following conditions were used: $95^{\circ} \mathrm{C}$ for $10 \mathrm{~min}, 40$ cycles of $95^{\circ} \mathrm{C}$ for $15 \mathrm{~s}$, and $60^{\circ} \mathrm{C}$ for $1 \mathrm{~min}$. The relative gene expression was calculated with the $2^{-\Delta \Delta \mathrm{Ct}}$ method, using B2M (Hs00187842_m1) as the housekeeping gene. The experiment was performed with technical triplicates.

\section{Statistical analyses}

Data were analyzed with statistical software (SPSS 22.0; SPSS, Chicago, III, USA). All values are reported as mean \pm SD. A Chi-Square test was used to test the equality of proportions. The normality of data was assessed by the Shapiro-Wilk test. The differences in gene expression levels and age, sex, $\mathrm{pH}$ of brain tissue and PMI between groups were analyzed using the independentsample $t$-test in normal distribution data and the Mann-Whitney $U$ test in non-normal distributions. The Pearson correlation coefficient was used to measure the strength between two continuous variables. Levene's test was used to determine the variance between the two groups, and $p$-value of $<0.05$ was considered statistically significant.

\section{Results}

A matched case-control design was used to minimize the variability among the groups. The groups were matched by age, sex, $\mathrm{pH}$ of brain tissue, and PMI. The main characteristics of the subjects are provided in Table 1. Based on the classification used by Stenbacka [24], our suicide sample was mostly violent suicides such as hanging and gunshot wounds (86.67 \%). There were no significant differences in age $(t=0.153, p=0.879), \mathrm{pH}(t=1.035, p=0.309)$, or PMI $(t=1.383, p=0.178)$. 
Significant differences in HTR2A expression in the prefrontal cortex between suicide victims and

147 control subjects $(t=2.860, p=0.008)$ were observed. HTR2A had higher expression levels in 148 suicide victims than controls ( $0.8341 \pm 0.30083$ vs $0.4999 \pm 0.32871)$ (Figure 1-A). Furthermore, we 149 found a significant trend in the hypothalamus region $(p=0.067)$ (Figure 1-B).

\section{MAOA expression pattern}

152 The expression of the MAOA gene showed no significant differences in the prefrontal cortex 153 between the 15 suicide victims and 15 control subjects $(t=-1.067, p=0.295)$ (Figure 2-A). 154 However, the expression of MAOA was significantly increased in the hypothalamus $(t=2.464, p=$ 1550.020 ) in suicide victims, as compared with that in control subjects (Figure 2-B).

\section{Subgroup analysis}

158 The effect of sex on the expression of HTR2A and MAOA genes was evaluated. In men, which is the majority group in both suicides $(n=13)$ and controls $(n=13)$, significant differences were maintained (HTR2A in prefrontal cortex: $t=3.234, p=0.004 ;$ MAOA in hypothalamus: $t=2.025, p$ $=0.054)$. Further, no significant changes were observed when comparing the expression profile of

162 violent and non-violent methods of suicide, (HTR2A in prefrontal cortex: $t=3.479, p=0.021$; MAOA in hypothalamus: $t=2.457, p=0.054)$. Also, the expression pattern was evaluated across

164 age groups, based on the classification established by the WHO: youth as the 15-24-year age group 165 and adult as the 25-59 year age group [25]. Interestingly, in the adult subgroup (suicide subjects $\mathrm{n}$ $166=10$; control subjects $\mathrm{n}=10$ ) the only difference observed in the pattern of HTR2A expression 167 gene in the prefrontal cortex was maintained $(p=0.017)$, and a significant decrease in HTR2A 168 expression in the hypothalamic area was observed $(p=0.011)$ (Figure 3$)$. 
171 The Pearson correlation coefficient was used to measure the effect of $\mathrm{PMI}$ and $\mathrm{pH}$ on the 172 expression levels of HTR2A and MAOA. None had any significant effects (data not shown).

174 Discussion

175 Most studies exclusively report the expression levels of HTR2A and MAOA in the Caucasian 176 population except for the study by Pandey et al. [15], which included different racial origins.

177 To our knowledge, this is the first study that has investigated the expression pattern of the 5- $\mathrm{HT}_{2 \mathrm{~A}}$ 178 receptor and the enzyme MAO-A in the postmortem brain of suicide victims from a Mexican 179 population. Our results show that HTR2A and MAOA expression levels were increased in the prefrontal cortex and hypothalamus of suicide victims, respectively. Also, we observed a 181 significant decrease in HTR2A expression in the hypothalamus of the adult subgroup of suicidal 182 victims. The results shown here support previous studies that suggest that suicide may be 183 associated with serotonin abnormalities mediated by the serotonin $2 \mathrm{~A}$ receptor and the MAO-A 184 enzyme.

186 Previous studies provided evidence of an increase in $5-\mathrm{HT}_{2 \mathrm{~A}}$ receptor protein levels in the frontal 187 cortices of suicide victims compared with controls by receptor binding assays [12-15]. Cortical 5$188 \mathrm{HT}_{2 \mathrm{~A}}$ receptors have mainly been observed on layer $\mathrm{V}$ pyramidal cells, and it has been 189 hypothesized that activation of this metabotropic receptor may be responsible for mediating the 190 depolarization of GABAergic cortical interneurons [26]. There is evidence that 5-HT and DOI (2,5191 dimethoxy-4-iodoamphetamine) a selective $5-\mathrm{HT}_{2 \mathrm{~A}}$ receptor antagonist, may reversibly reduce 192 GABA-activated currents [27]. Interestingly, low GABRG2 expression [28], and alpha1, alpha3, 193 alpha4, and delta GABA(A) receptor subunits [29] have been reported in the frontal cortex of 
suicide victims. Thus, it is possible that the attenuated activity of GABAergic interneurons

195 mediated by the $5-\mathrm{HT}_{2 \mathrm{~A}}$ receptors located on the pyramidal neurons can lead to a dysregulation of

196 the mesocortical dopaminergic system. Morphological and pharmacological evidence suggests

197 that there is a reciprocal interaction between the dopaminergic and serotonergic systems [30, 31],

198 strengthening the previous hypothesis. Further, it has been reported that the dopamine circuitry is

199 likely involved in mediating depressive-like behaviors and social withdrawal [32], impulsive

200 aggression [33], and anxiety [34], which are traits that might contribute to the risk of suicidal

201 behavior [3].

202

203 Another important observation of our study is the significant increase in the expression of the

204 MAOA gene in the hypothalamus of suicide subjects. This result is consistent with a previous

205 report of a significant elevation in MAO-A activity in the hypothalamic region of suicide victims

206 [19] and with the reduction of 5-HT in the hypothalamus of this group [35]. Despite the

207 mechanisms by which MAO-A can be associated with suicide being unclear, we hypothesized that

208 the increase of $M A O A$ expression in the hypothalamus of suicide victims could affect the activation

209 of the hypothalamic-pituitary-adrenal (HPA) axis. The study by Mehlhem et al., [36] suggest that a

210 blunted HPA axis activity increases the risk for suicide, possibly by a reduced ability to respond

211 adaptively to stressors. Likewise, low cortisol levels have been associated with suicidal behavior

212 [37] [38]. 5-HT can regulate the HPA axis via serotonin $2 \mathrm{C}$ receptor stimulation in the

213 paraventricular nucleus of the hypothalamus (PVH) [39]. This may imply that the blunted HPA axis

214 functioning may be a result of low circulating levels of 5-HT due to the increased expression of

215 MAOA. Future research is needed to examine this theory. 
217 It should be noted that our findings at the mRNA level are consistent with previous reports at the 218 protein level in different populations [12-15, 19]. Interestingly, the 25-59 year-old age group 219 showed a significant decrease in HTR2A expression in the hypothalamic area of suicide victims $(p=$ 220 0.011). In accordance to Turecki and Brent (2016) impulsive aggression, conduct disorder, and 221 antisocial behavior are more salient in youth suicide, whereas mood disorders are usually 222 observed with increasing age. We hypothesized that a decrease of HTR2A expression may be 223 related to the increased expression of the MAOA gene observed in the hypothalamus of suicide 224 victims. It has been argued that the PVH nucleus participates in mood modulation, this is the 225 primary driver of HPA axis responses, and interestingly, the $5-\mathrm{HT}_{2 \mathrm{~A}}$ receptors are present on 226 neuroendocrine cells of this limbic nucleus [40]. The evidence suggests that the HPA axis 227 dysfunction and maladaptive responses to stress may be associated with the pathophysiology of 228 mood disorders [41] and suicidal behavior [36]. Future studies that directly asses the $5-\mathrm{HT}_{2 \mathrm{~A}}$ 229 receptors in PVH may clarify whether alterations in 5-HT signaling may result in a HPA axis 230 imbalance in suicide victims.

232 There are several limitations to our study. The psychiatric diagnosis of subjects may be a source of 233 heterogeneity. Because our study is based on a case-control design, temporality could not be 234 inferred with certainty. Another limitation present in this study is the lack of genotype data for 235 subjects, since gene variants may influence the expression of the HTR2A gene [42-44] and the 236 MAOA gene $[45,46]$. In this study, it was not possible to obtain the toxicological data due to legal 237 issues and information privacy. 
240 In conclusion, our study suggests that the differential expression pattern of the HTR2A gene in the

241 prefrontal cortex and hypothalamus, as well as the MAOA gene in the hypothalamus are involved

242 in suicide. We propose that both molecules may serve as important vulnerability factors to suicide.

243

244 List of abbreviations

245 5-HT, 5-hydroxytryptamine; 5-HIAA, 5-Hydroxyindoleacetic acid; 5- $\mathrm{HT}_{2 \mathrm{~A}}$, 5-hydroxytryptamine

246 receptor $2 \mathrm{~A} ; B 2 \mathrm{M}, \quad 32$ microglobulin gene; DOI, 2,5-dimethoxy-4-iodoamphetamine; GABA, 247 gamma-Aminobutyric acid; HTR2A, 5-hydroxytryptamine receptor 2A gene; HPA, hypothalamic, 248 pituitary, adrenal; MAOA, Monoamine oxidase A gene; MAO-A, Monoamine oxidase A enzyme; 249 KO, Knockout; PMI, postmortem interval; PVH, paraventricular nucleus of the hypothalamus; 250 WHO, World Health Organization.

252 Ethics approval and consent to participate

253 All participants signed the informed consent. The study adhered to the

254 tenets of the Declaration of Helsinki and was approved by the Ethics Committee of the General 255 Hospital of Durango (CEI 2016/33).

\section{Consent for publication}

258 Not applicable.

\section{Availability of data and materials}

261 The datasets used and/or analyzed during the current study are available from the corresponding 262 author on reasonable request. 
265 The authors declare that they have no competing interests.

266

267 Funding

268 This study was supported by grant from the National Council for Science and Technology

269 (CONACYT: \#261453).

270 Author Contributions

271 DRR and MBS conceived the study, participated in its design, and draft the manuscript. DRR,

272 EMMH, helped to perform the statistical analysis and to draft the manuscript. JSP, NUE and ACSL

273 helped with data integration and analysis. All authors read and approved the final manuscript.

274 Acknowledgments

275 The authors thank the staff of the forensic medical service from the Forensic Medical Services of

276 the General Fiscally for their technical assistance.

277 References

278 1. Bilsen J: Suicide and Youth: Risk Factors. Front Psychiatry 2018, 9:540.

279 https://doi.org/10.3389/fpsyt.2018.00540

280 2. Romero-Pimentel AL, Mendoza-Morales RC, Fresan A, Garcia-Dolores F, Gonzalez-Saenz

281 EE, Morales-Marin ME, Nicolini H, Borges G: Demographic and Clinical Characteristics of

282 Completed Suicides in Mexico City 2014-2015. Front Psychiatry 2018, 9:402.

283 https://doi.org/10.3389/fpsyt.2018.00402

284 3. Turecki G, Brent DA: Suicide and suicidal behaviour. Lancet 2016, 387:1227-1239.

285 https://doi.org/10.1016/S0140-6736(15)00234-2

286 4. Roy A, Agren H, Pickar D, Linnoila M, Doran AR, Cutler NR, Paul SM: Reduced CSF

287 concentrations of homovanillic acid and homovanillic acid to 5-hydroxyindoleacetic acid ratios in 288 depressed patients: relationship to suicidal behavior and dexamethasone nonsuppression. Am J 289 Psychiatry 1986, 143:1539-1545. https://doi.org/10.1176/ajp.143.12.1539 
290 5. Nordstrom P, Samuelsson M, Asberg M, Traskman-Bendz L, Aberg-Wistedt A, Nordin C, 291 Bertilsson L: CSF 5-HIAA predicts suicide risk after attempted suicide. Suicide Life Threat Behav 292 1994, 24:1-9. PMID: 7515519

293 6. Ohmori T, Arora RC, Meltzer HY: Serotonergic measures in suicide brain: the concentration 294 of 5-HIAA, HVA, and tryptophan in frontal cortex of suicide victims. Biol Psychiatry 1992, 32:57-71. 295 https://doi.org/10.1016/0006-3223(92)90142-M

2967 Mann JJ, Arango V, Marzuk PM, Theccanat S, Reis DJ: Evidence for the 5-HT hypothesis of 297 suicide. A review of post-mortem studies. $\mathrm{Br} J$ Psychiatry Suppl 1989:7-14. 298 https://doi.org/10.1192/S000712500029171X

299 8. Antypa N, Serretti A, Rujescu D: Serotonergic genes and suicide: a systematic review. Eur 300 Neuropsychopharmacol 2013, 23:1125-1142. https://doi.org/10.1016/j.euroneuro.2013.03.013

301 9. Gonzalez-Castro TB, Tovilla-Zarate C, Juarez-Rojop I, Pool Garcia S, Velazquez-Sanchez MP, 302 Genis A, Nicolini H, Lopez Narvaez L: Association of the 5HTR2A gene with suicidal behavior: case303 control study and updated meta-analysis. BMC Psychiatry 2013, 13:25. 304 https://doi.org/10.1186/1471-244X-13-25

305 10. Courtet P, Jollant F, Buresi C, Castelnau D, Mouthon D, Malafosse A: The monoamine 306 oxidase A gene may influence the means used in suicide attempts. Psychiatr Genet 2005, 15:189307 193. https://doi.org/10.1097/00041444-200509000-00009

308 11. Forutan F, Estalji S, Beu M, Nikolaus S, Hamacher K, Coenen HH, Vosberg H, Muller-Gartner $309 \mathrm{HW}$, Larisch R: Distribution of 5HT2A receptors in the human brain: comparison of data in vivo and 310 post mortem. Nuklearmedizin 2002, 41:197-201. PMID: 12224404

311 12. Turecki G, Briere R, Dewar K, Antonetti T, Lesage AD, Seguin M, Chawky N, Vanier C, Alda $312 M$, Joober $R$, et al: Prediction of level of serotonin $2 A$ receptor binding by serotonin receptor $2 A$ 313 genetic variation in postmortem brain samples from subjects who did or did not commit suicide. 314 Am J Psychiatry 1999, 156:1456-1458. https://doi.org/10.1176/ajp.156.9.1456

315 13. Stanley M, Mann JJ: Increased serotonin-2 binding sites in frontal cortex of suicide victims. 316 Lancet 1983, 1:214-216. https://doi.org/10.1016/S0140-6736(83)92590-4

317 14. Mann JJ, Stanley M, McBride PA, McEwen BS: Increased serotonin2 and beta-adrenergic 318 receptor binding in the frontal cortices of suicide victims. Arch Gen Psychiatry 1986, 43:954-959. 319 https://doi.org/10.1001/archpsyc.1986.01800100048007

320 15. Pandey GN, Dwivedi Y, Rizavi HS, Ren X, Pandey SC, Pesold C, Roberts RC, Conley RR, 321 Tamminga CA: Higher expression of serotonin 5-HT(2A) receptors in the postmortem brains of 
teenage suicide victims. Am J Psychiatry 2002, 159:419-429.

323 https://doi.org/10.1176/appi.ajp.159.3.419

324 16. Ozelius L, Hsu YP, Bruns G, Powell JF, Chen S, Weyler W, Utterback M, Zucker D, Haines J, 325 Trofatter JA, et al.: Human monoamine oxidase gene (MAOA): chromosome position (Xp21-p11) and DNA polymorphism. Genomics 1988, 3:53-58. https://doi.org/10.1016/0888-7543(88)90159-0

327 17. Du L, Faludi G, Palkovits M, Sotonyi P, Bakish D, Hrdina PD: High activity-related allele of 328 MAO-A gene associated with depressed suicide in males. Neuroreport 2002, 13:1195-1198. 329 https://doi.org/10.1097/00001756-200207020-00025

330 18. Lung FW, Tzeng DS, Huang MF, Lee MB: Association of the MAOA promoter uVNTR 331 polymorphism with suicide attempts in patients with major depressive disorder. BMC Med Genet 332 2011, 12:74 https://doi.org/10.1186/1471-2350-12-74

333 19. Sherif F, Marcusson J, Oreland L: Brain gamma-aminobutyrate transaminase and 334 monoamine oxidase activities in suicide victims. Eur Arch Psychiatry Clin Neurosci 1991, 241:139144. https://doi.org/10.1007/BF02219712

336 20. Vishnivetskaya GB, Skrinskaya JA, Seif I, Popova NK: Effect of MAO A deficiency on 337 different kinds of aggression and social investigation in mice. Aggress Behav 2007, 33:1-6. 338 https://doi.org/10.1002/ab.20161

339 21. Shih JC, Chen K, Ridd MJ: Monoamine oxidase: from genes to behavior. Annu Rev Neurosci 340 1999, 22:197-217. https://doi.org/10.1146/annurev.neuro.22.1.197

341 22. Weisstaub NV, Zhou M, Lira A, Lambe E, Gonzalez-Maeso J, Hornung JP, Sibille E, 342 Underwood M, Itohara S, Dauer WT, et al: Cortical 5-HT2A receptor signaling modulates anxiety343 like behaviors in mice. Science 2006, 313:536-540. https://doi.org/10.1126/science.1123432

344 23. Sher L, Oquendo MA, Galfalvy HC, Grunebaum MF, Burke AK, Zalsman G, Mann JJ: The 345 relationship of aggression to suicidal behavior in depressed patients with a history of alcoholism.

346 Addict Behav 2005, 30:1144-1153. https://doi.org/10.1016/j.addbeh.2004.12.001

347 24. Stenbacka M, Jokinen J: Violent and non-violent methods of attempted and completed 348 suicide in Swedish young men: the role of early risk factors. BMC Psychiatry 2015, 15:196. 349 https://doi.org/10.1186/s12888-015-0570-2

350 25. Weiss HA, Ferrand RA: Improving adolescent health: an evidence-based call to action. 351 Lancet 2019, 393:1073-1075. https://doi.org/10.1016/s0140-6736(18)32996-9 
352 26. Weber ET, Andrade R: Htr2a Gene and 5-HT(2A) Receptor Expression in the Cerebral

353 Cortex Studied Using Genetically Modified Mice. Front Neurosci 2010, 4.

354 https://dx.doi.org/10.3389\%2Ffnins.2010.00036

355 27. Wang H, Hu L, Liu C, Su Z, Wang L, Pan G, Guo Y, He J: 5-HT2 receptors mediate functional 356 modulation of GABAa receptors and inhibitory synaptic transmissions in human iPS-derived 357 neurons. Sci Rep 2016, 6:20033. https://doi.org/10.1038/srep20033

358 28. Yin H, Pantazatos SP, Galfalvy H, Huang YY, Rosoklija GB, Dwork AJ, Burke A, Arango V, 359 Oquendo MA, Mann JJ: A pilot integrative genomics study of GABA and glutamate neurotransmitter systems in suicide, suicidal behavior, and major depressive disorder. Am J Med Genet B Neuropsychiatr Genet 2016, 171B:414-426. https://doi.org/10.1002/ajmg.b.32423

362 29. Merali Z, Du L, Hrdina P, Palkovits M, Faludi G, Poulter MO, Anisman H: Dysregulation in 363 the suicide brain: mRNA expression of corticotropin-releasing hormone receptors and GABA(A) receptor subunits in frontal cortical brain region. J Neurosci 2004, 24:1478-1485. https://doi.org/10.1523/jneurosci.4734-03.2004

366 30. Kapur S, Remington G: Serotonin-dopamine interaction and its relevance to schizophrenia. 367 Am J Psychiatry 1996, 153:466-476. https://doi.org/10.1176/ajp.153.4.466

368 31. Wong PT, Feng H, Teo WL: Interaction of the dopaminergic and serotonergic systems in 369 the rat striatum: effects of selective antagonists and uptake inhibitors. Neurosci Res 1995, 23:115370119.

371 32. Knowland D, Lim BK: Circuit-based frameworks of depressive behaviors: The role of reward 372 circuitry and beyond. Pharmacol Biochem Behav 2018, 174:42-52. https://doi.org/10.1016/0168373 0102(95)90023-3

374 33. Seo D, Patrick CJ, Kennealy PJ: Role of Serotonin and Dopamine System Interactions in the 375 Neurobiology of Impulsive Aggression and its Comorbidity with other Clinical Disorders. Aggress 376 Violent Behav 2008, 13:383-395. https://doi.org/10.1016/j.avb.2008.06.003

377 34. Cha J, Carlson JM, Dedora DJ, Greenberg T, Proudfit GH, Mujica-Parodi LR: Hyper-reactive 378 human ventral tegmental area and aberrant mesocorticolimbic connectivity in overgeneralization 379 of fear in generalized anxiety disorder. J Neurosci 2014, 34:5855-5860. 380 https://doi.org/10.1523/jneurosci.4868-13.2014

381 35. Korpi ER, Kleinman JE, Goodman SI, Phillips I, DeLisi LE, Linnoila M, Wyatt RJ: Serotonin 382 and 5-hydroxyindoleacetic acid in brains of suicide victims. Comparison in chronic schizophrenic 
patients with suicide as cause of death. Arch Gen Psychiatry 1986, 43:594-600. https://doi.org/10.1001/archpsyc.1986.01800060088011

36. Melhem NM, Munroe S, Marsland A, Gray K, Brent D, Porta G, Douaihy A, Laudenslager ML, DePietro F, Diler R, et al: Blunted HPA axis activity prior to suicide attempt and increased inflammation in attempters. Psychoneuroendocrinology 2017, 77:284-294. https://doi.org/10.1016/j.psyneuen.2017.01.001

37. Papadopoulou A, Douzenis A, Christodoulou C, Gournellis R, Papageorgiou C, Markianos M: Association of Plasma Cortisol Levels with Clinical Characteristics of Suicide Attempters. Neuropsychobiology 2017, 76:161-165. https://doi.org/10.1159/000489782

38. O'Connor DB, Ferguson E, Green JA, O'Carroll RE, O'Connor RC: Cortisol levels and suicidal behavior: A meta-analysis. Psychoneuroendocrinology 2016, 63:370-379. https://doi.org/10.1016/j.psyneuen.2015.10.011

39. Heisler LK, Pronchuk N, Nonogaki K, Zhou L, Raber J, Tung L, Yeo GS, O'Rahilly S, Colmers WF, Elmquist JK, Tecott LH: Serotonin activates the hypothalamic-pituitary-adrenal axis via serotonin 2C receptor stimulation. J Neurosci 2007, 27:6956-6964. https://doi.org/10.1523/JNEUROSCI.2584-06.2007

40. Zhang Y, Damjanoska KJ, Carrasco GA, Dudas B, D'Souza DN, Tetzlaff J, Garcia F, Hanley NR, Scripathirathan K, Petersen BR, et al: Evidence that 5-HT2A receptors in the hypothalamic paraventricular nucleus mediate neuroendocrine responses to (-)DOI. J Neurosci 2002, 22:96359642. https://doi.org/10.1523/jneurosci.22-21-09635.2002

41. Bao AM, Swaab DF: The human hypothalamus in mood disorders: The HPA axis in the center. IBRO Rep 2019, 6:45-53. https://doi.org/10.1016/j.ibror.2018.11.008

42. Falkenberg VR, Gurbaxani BM, Unger ER, Rajeevan MS: Functional genomics of serotonin receptor 2A (HTR2A): interaction of polymorphism, methylation, expression and disease association. Neuromolecular Med 2011, 13:66-76. https://doi.org/10.1007/s12017-010-8138-2

43. Polesskaya OO, Sokolov BP: Differential expression of the " $\mathrm{C}$ " and "T" alleles of the 5-HT2A receptor gene in the temporal cortex of normal individuals and schizophrenics. J Neurosci Res 2002, 67:812-822. https://doi.org/10.1002/jnr.10173

44. Myers RL, Airey DC, Manier DH, Shelton RC, Sanders-Bush E: Polymorphisms in the regulatory region of the human serotonin 5-HT2A receptor gene (HTR2A) influence gene expression. Biol Psychiatry 2007, 61:167-173. https://doi.org/10.1016/j.biopsych.2005.12.018 
414 45. Zhang H, Smith GN, Liu X, Holden JJ: Association of MAOA, 5-HTT, and NET promoter 415 polymorphisms with gene expression and protein activity in human placentas. Physiol Genomics 416 2010, 42:85-92. https://doi.org/10.1152/physiolgenomics.00220.2009

417 46. Manca M, Pessoa V, Lopez Al, Harrison PT, Miyajima F, Sharp H, Pickles A, Hill J, 418 Murgatroyd C, Bubb VJ, Quinn JP: The Regulation of Monoamine Oxidase A Gene Expression by 419 Distinct Variable Number Tandem Repeats. J Mol Neurosci 2018, 64:459-470. 420 https://doi.org/10.1007/s12031-018-1044-z

421

422 Figure 1. Expression levels of HTR2A in the postmortem brain. (A) Relative HTR2A expression in 423 the prefrontal cortex (BA 8/9). (B) Relative HTR2A expression in the hypothalamus. The data are 424 shown as fold change in mRNA levels and fold change was calculated based on $\mathbf{2}^{-\Delta \Delta \mathrm{Ct}}$ values. 425 Error bars indicate 95\% confidence intervals.

426

427 Figure 2. Expression levels of MAOA in the postmortem brain. (A) Relative MAOA expression in 428 the prefrontal cortex (BA 8/9). (B) Relative MAOA expression in the hypothalamus. The data are 429 shown as fold change in mRNA levels and fold change was calculated based on $2^{-\Delta \Delta C t}$ values. Error 430 bars indicate $95 \%$ confidence intervals.

431

432 Figure 3. Expression levels of HTR2Ain the hypothalamus of adult sample (25-59 year-old age 433 group). The data are shown as fold change in mRNA levels and fold change was calculated based 434 on $2^{-\Delta \Delta \mathrm{Ct}}$ values. Error bars indicate $95 \%$ confidence intervals.

435

436 Table 1. Main characteristics of the subjects

\begin{tabular}{cccc}
\hline & Suicide victims & Control subjects & $p$ \\
\hline Sex, Male/Female & $13 / 2$ & $13 / 2$ & $1^{*}$ \\
\hline Age at death (years) & $32.07 \pm 12.40$ & $31.4 \pm 11.41$ & $0.879+$
\end{tabular}




\begin{tabular}{|c|c|c|c|}
\hline PMI (hours) & $6.26 \pm 2.63$ & $4.86 \pm 2.90$ & $0.178+$ \\
\hline $\mathrm{pH}$ & $6.19 \pm 0.30$ & $6.06 \pm 0.37$ & $0.309+$ \\
\hline \multicolumn{4}{|l|}{ Cause of death, (\%) } \\
\hline & Hanging (80) & Accident (multiple injuries) (86.6) & \\
\hline & Poisoning (13.33) & Myocardial infarction (6.67) & \\
\hline & Gunshot wound (6.67) & Drowning (6.67) & \\
\hline \multicolumn{4}{|l|}{ Diagnosis, n (\%) } \\
\hline $\begin{array}{l}\text { Alcohol abuse } \\
\text { /dependence }\end{array}$ & $1(6.67)$ & $1(6.67)$ & $1^{*}$ \\
\hline Drug abuse /dependence & $1(6.67)$ & $1(6.67)$ & $1^{*}$ \\
\hline Major depression & $2(13.33)$ & $0(0)$ & $0.143^{*}$ \\
\hline
\end{tabular}

437

438 Values are expressed as mean \pm SD. PMI $=$ post-mortem interval; ${ }^{*}=$ Chi-Square test $;+=$ independent $t$-test 
Figures

\section{A}

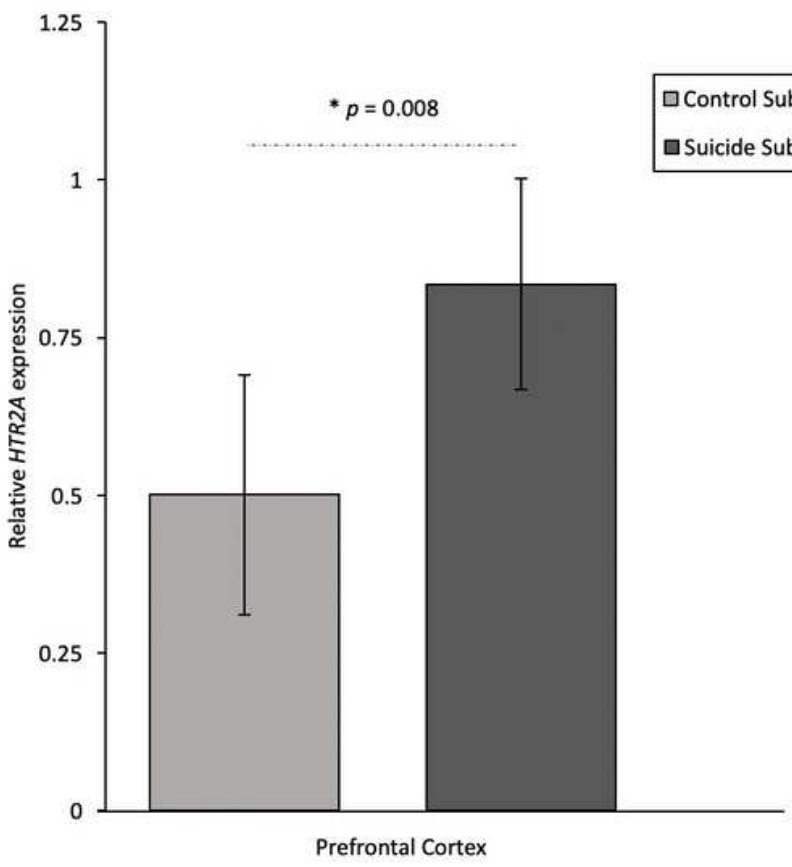

\section{B}

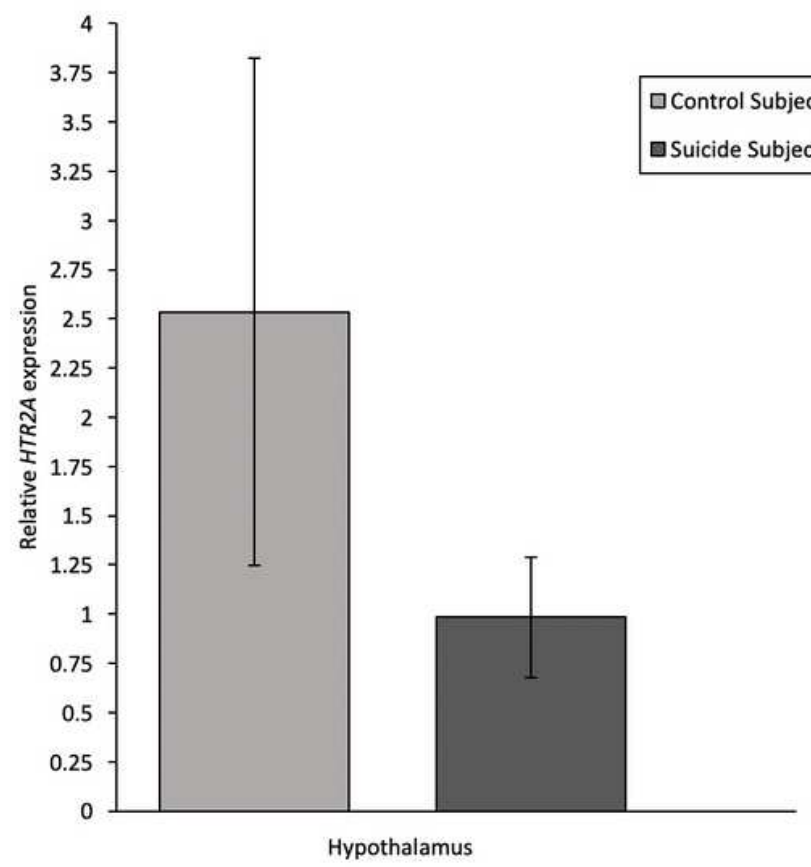

\section{Figure 1}

Expression levels of HTR2A in the postmortem brain. (A) Relative HTR2A expression in the prefrontal cortex (BA 8/9). (B) Relative HTR2A expression in the hypothalamus. The data are shown as fold change

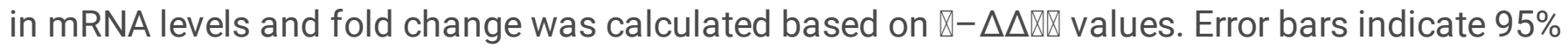
confidence intervals. 


\section{A}

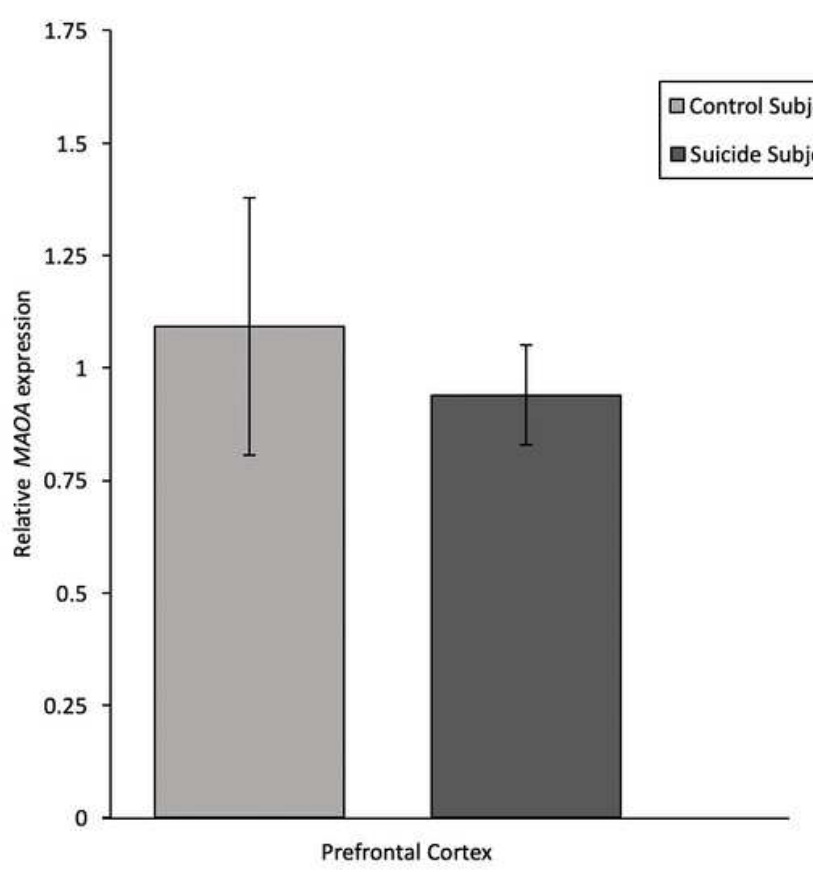

\section{B}

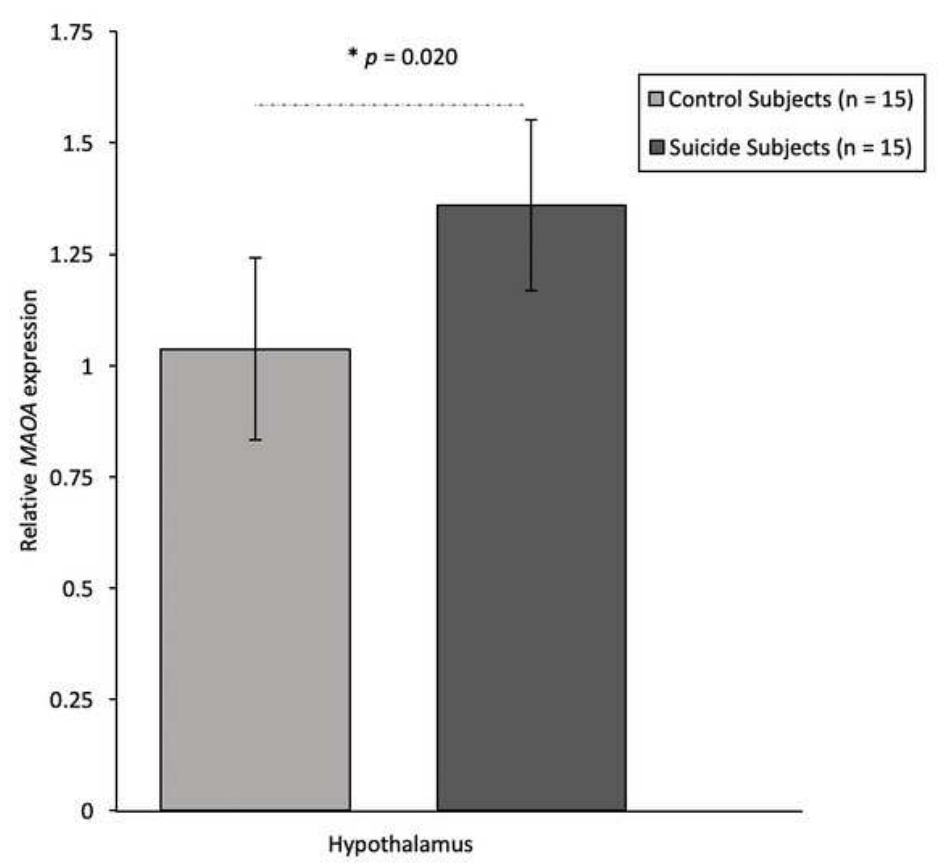

Figure 2

Expression levels of MAOA in the postmortem brain. (A) Relative MAOA expression in the prefrontal cortex (BA 8/9). (B) Relative MAOA expression in the hypothalamus. The data are shown as fold change in mRNA levels and fold change was calculated based on $2-\Delta \Delta$ !" values. Error bars indicate $95 \%$ confidence intervals. 


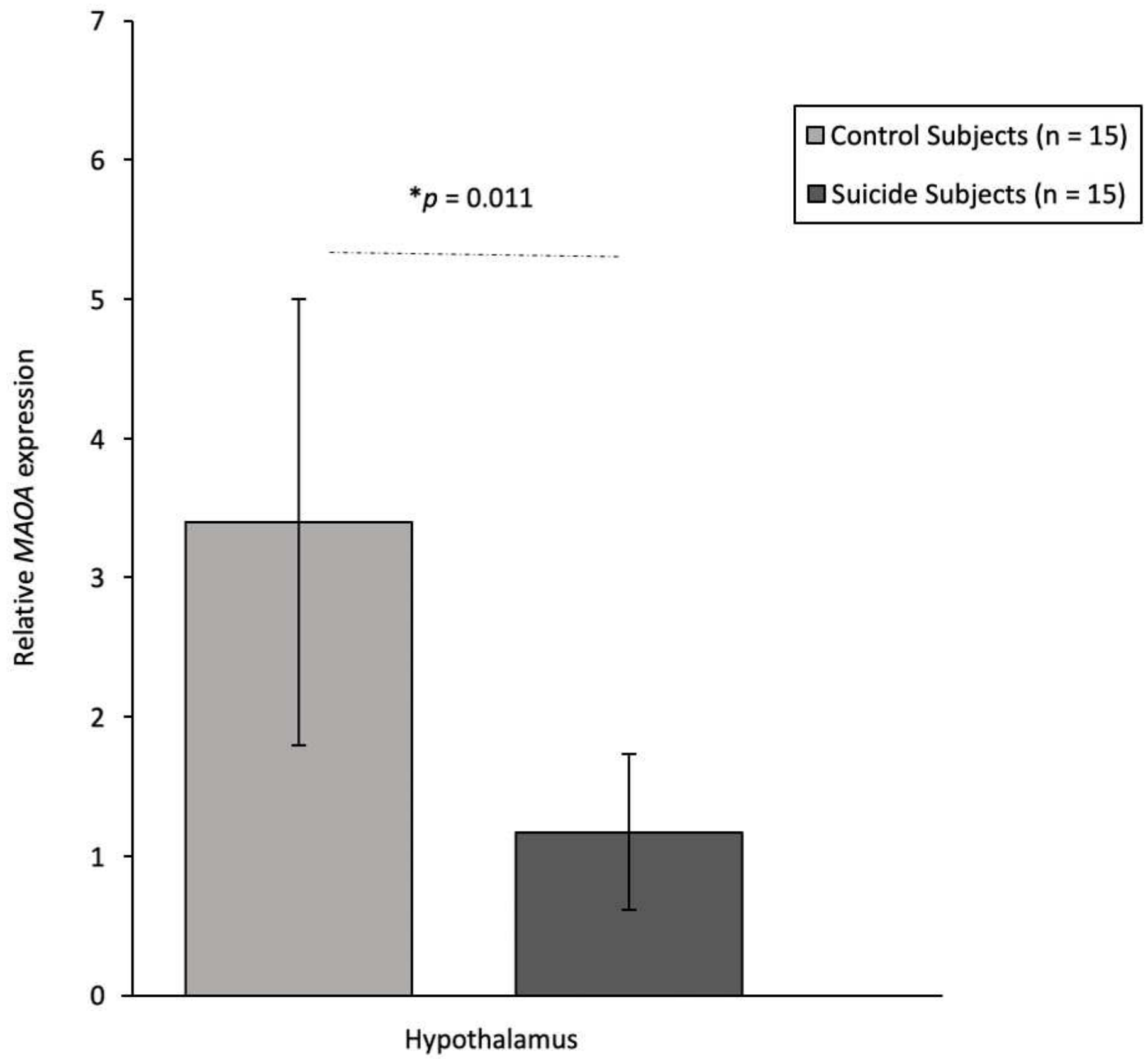

Figure 3

Expression levels of HTR2Ain the hypothalamus of adult sample (25-59 year-old age group). The data are shown as fold change in mRNA levels and fold change was calculated based on $2-\Delta \Delta !$ !" values. Error bars indicate $95 \%$ confidence intervals. 